\title{
Bone marrow transplantation for sickle cell disease
}

The very natural response to the first report of bone marrow transplant (BMT) for sickle cell disease five years ago in $1988^{1}$ was to question both the rationale and ethics behind the decision and to ponder on the mortality and morbidity, both immediate and long term. ${ }^{2}$ Over the succeeding five years, the debate has changed.

\section{Life with sickle cell disease}

We are all aware of the great variability in clinical severity of sickle cell disease. There are people with the disease who are only aware of their diagnosis because they were screened before a general anaesthetic or as part of a community programme. Such people are in the minority and most people suffer clinical symptoms of variable severity from time to time. A smaller number are admitted frequently for painful vaso-occlusive crisis while all patients, regardless of the frequency of painful crisis, are at risk of life threatening complications, most particularly stroke and sickle lung problems. Life with sickle cell disease can be so difficult that some parents even say they would opt for BMT even if the mortality was $\geqslant 90 \%{ }^{3}$

The National Cooperative Study of Sickle Cell Disease in North America has shown that $15 \%$ of children with the homozygous SS type of sickle cell disease will die before the age of $20 .{ }^{4}$ The probability of living to age 20 , when all types of sickle cell disease are considered, is $89 \%$, while $50 \%$ will be dead by the age of 40 .

\section{Morbidity associated with BMT}

In Europe the discussion of BMT for sickle cell disease relates to fully histocompatible sibling donors. To determine the probable morbidity for BMT in this situation we can look to the data available for BMT for $\beta$ thalassaemia major, ${ }^{56}$ aplastic anaemia, and those patients with sickle cell disease who have already been transplanted. The acute toxicities, including nausea, mucositis, and cytopenias, are all treatable, while interstitial pneumonia is generally preventable or treatable. Acute graft versus host disease (GVHD), when the donor is fully histocompatible and prophylaxis with methotrexate and cyclosporin is used, occurs in $<10 \%$ of cases. Most acute GVHD is mild to moderate and no severe cases have been reported for BMT in sickle cell disease. Chronic GVHD is likely to be suffered by only $1 \%$ severely and around $5 \%$ moderately or mildly. Six of the reported 52 cases of BMT for sickle cell disease are known not to have fully engrafted with four showing partial chimaerism.

The long term complications of BMT in sickle cell disease are more difficult to extrapolate, but the results are likely to be closely related to the preparative regimen used, so that there may be effects on growth and fertility with a low, but definite, risk of developing malignancy. It seems reasonable, at present, to consider the risk of death or severe morbidity to be in the region of $10 \%$ for BMT in sickle cell disease. ${ }^{7}$

\section{Markers of severity in sickle cell disease}

There is, unfortunately, no clear objective marker from which we can predict severity in sickle cell disease. There are a number of measurable factors which, when looked at between populations, suggest a modification of the clinical course of sickle cell disease. However, physicians cannot and should not take any of these measures, singly or in combination, and try to predict the likely severity of the disease in any individual. The most important of these are:

- The persistent production into adult life of raised concentrations of fetal haemoglobin $(\geqslant 10 \% \mathrm{HbF}$ offers protection against stroke while $\geqslant 20 \% \mathrm{HbF}$ offers protection from painful crisis and pulmonary complications). ${ }^{8}$

- Coinheritance of $\alpha$ thalassaemia that reduces the level of haemolysis. ${ }^{9}$

- The $\beta^{\text {s }}$ gene cluster haplotype map pattern has been shown to have some association with end organ failure. ${ }^{10}$

The only clinical marker for severity in young children appears to be pain. The American National Cooperative Study has shown that a risk factor for severity is a first painful crisis, or hand-foot syndrome, before the age of 2 years. ${ }^{11}$

We therefore remain unable, at the present time, to predict the clinical course for any patient before they have suffered multiple painful crises or a potentially catastrophic complication of their sickle cell disease.

\section{BMT for sickle cell disease}

BMT can be successfully undertaken in sickle cell disease, resulting in a peripheral blood phenotype of HbAA or AS, depending on that of the donor. Over 50 BMTs have now been performed worldwide. We expect the best results to be in those who are transplanted young and before significant organ damage has developed as is the case for BMT for other diagnoses.

\section{Selection criteria for BMT in sickle cell disease}

It is arguable that if we continue to improve the care of patients with sickle cell disease, as we have done over the last two decades, then we will prevent mortality and there will be very few childhood and adolescent deaths related to the disease. Progress has resulted in the mortality during the first decade of life from sickle cell disease falling from $15 \%$ to $1 \%, 12$ but there is a possibility that the survival curve is just being shifted so that deaths occur in adolescence and early adult life instead of infancy.

British Paediatric Haematology Forum: criteria for selection of sickle cell disease patients for BMT

Acceptance

1 Informed family (including patient) consent

$2 \leqslant 16$ years +HLA matched sibling

3 (i) Sickle cell disease related neurological deficit, cerebrovascular

(i)

(ii) a $\geqslant 2$ episodes acute sickle chest syndrome

b Stage I chronic single lung disease

(iii) Recurrent severe and debilitating pain due to sickle cell disease 4 Problems respecting future medical care

Exclusions

1 Donor with a 'major' haemoglobinopathy

2 One or more of the following conditions:

Karnofsky performance $<70 \%$

Major intellectual impairment

Major intellectual impairment

Portal fibrosis: moderate and severe

Renal impairment (glomerular filtration rate $<\mathbf{3 0} \%$ predicted)

Stage III and IV sickle lung disease

Cardiomyopathy

HIV infection

*Not infective (exclude if lobar distribution, pathological isolate from blood

and sputum). problems with blood provision. 
An important question that has not yet been addressed is whether the presence of organ damage caused by sickle cell disease will prejudice the outcome of the transplant procedure itself. This may be particularly important for the neurological manifestations. Another issue unresolved by the present BMT studies and the literature relating to regular blood transfusion regimens and suppression of $\mathrm{HbS}$ production is whether progression of end organ damage will be halted or, even, whether there can be improvement or resolution of organ damage with time.

One of the most catastrophic events for children with sickle cell disease is stroke, which occurs in approximately $7 \%$ of children. ${ }^{13}$ All physicians in developed countries treat these children with hypertransfusion regimens with the associated low risk recurrence. Unfortunately, even after five to 12 years of transfusion treatment, there is a high risk of recurrence of stroke if the blood transfusions are stopped. ${ }^{14}$ These children are, therefore, faced with a life very similar to that of a child with $\beta$ thalassaemia major that is, possible lifelong transfusions with all the associated problems of iron overload. Life is even more complicated for children with sickle cell disease on hypertransfusion regimens as they have to be subjected to intermittent partial exchange transfusions in order to maintain a low percentage of haemoglobin S. If BMT is ethically acceptable for $\beta$ thalassaemia major then it must be considered for these children and others on hypertransfusion regimens.

The Paediatric Haematology Forum, a subcommittee of the British Society for Haematology which has British Paediatric Association representation, has now defined the recommended criteria for selection and exclusion for BMT in sickle cell disease as shown in the table. These criteria are to be used for a national controlled study with BMT performed in Birmingham and Manchester Children's
Hospitals and the Hammersmith Hospital. We intend to address the questions posed above by following up not only the children who have been transplanted but also those who qualify by the inclusion criteria for BMT but have no histocompatible sibling or refuse BMT.

Department of Haematology,

SALLY C DAVIES

Central Middlesex Hospital,

Acton Lane,

London NW10 7NS

1 Vermylen C, Fernandez-Robles E, Ninane J, Cornu G. Bone marrow transplantation in five children with sickle cell anaemia. Lancet 1988; i: 1427-8.

Weatherall DJ. Bone marrow transplantation for sickle cell anaemia. Lancet 1988; ii: 328.

3 Kodish E, Lantos J, Stocking C, Singer PA, Siegler M, Johnson FL. Bone marrow transplantation for sickle cell disease. A study of parents' decisions. $N$ Engl F Med 1991; 325: 1349-53.

4 Leikin SL, Gallagher D, Kinney TR, Sloane D, Klug P, Rida W, and the Cooperative Study of Sickle Cell Disease. Mortality in children and adolescents with sickle cell disease. Pediatrics 1989; 84: 500-8.

5 Lucarelli G, Galimberti M, Polchi P, et al. Bone marrow transplantation in patients with thalassemia. $N$ Engl 9 Med 1990; 322: 417-21.

6 Lucarelli $\mathrm{G}$, Weatherall DJ. Bone marrow transplantation for severe thalassaemia. Br $\mathcal{F}$ Haematol 1991; 78: 300-3.

7 Smith R. Using a mock trial to make a difficult decision. BMF 1992; 305, 1284-7.

8 Powars DR, Weiss JN, Chan LS, Schroeder WA. Is there a threshold level of fetal haemoglobin that ameliorates morbidity in sickle cell anemia? Blood 1984; 63: 921-6.

9 Higgs DR, Aldridge BE, Lamb J, et al. The interaction of alpha-thalassemia and homoxygous sickle-cell disease. N Engl F Med 1982; 306: 1441-6.

10 Powars DR. Sickle cell anemia: beta $S$ gene cluster haplotypes as prognostic indicators of vital organ failure. Semin Hematol 1991; 28: 202-8.

11 Muenz LR, Bray GL, Makris NG, Lessin LS, and the Cooperative Study of Sickle Cell Disease. Prediction of severity in sickle cell disease. Bone marrow transplantation for haemoglobinopathies workshop. Bethesda: National marrow transplantation for haemog

12 Vichinsky EP. Comprehensive care in sickle cell disease: its impact on morbidity and mortality. Semin Hematol 1991; 28: 220-6.

13 Powars DR. Natural history of sickle cell disease: the first ten years. Semin Hematol 1975; 12: 267-85.

14 Wang WC, Kovanar EH, Tompkin IL, et al. High risk of recurrent stroke after discontinuance of 5-12 years of transfusion therapy in patients with sickle cell disease. F Pediatr 1991; 118: 377-82.

\section{The value of urodynamic studies}

The International Continence Society has defined urodynamics as the assessment of the function and dysfunction of the urinary tract by any appropriate method. ${ }^{1}$ Such investigations may focus on the upper or lower urinary tract. Upper urinary tract urodynamic studies, which include measurement of the pressure and flow of urine from the renal pelvis to the ureter, may be of benefit in assessing difficult cases of possible pelviureteric junction obstruction. Confusion arises when the terms 'urodynamics' and 'urodynamic studies' are used to denote the specific measurement of the pressure/volume and flow relationships of the lower urinary tract. Such investigations are more correctly termed cystometric studies or cystometry and will be the main focus of this paper.

\section{Non-invasive urodynamic studies}

The initial assessment of any child with suspected lower urinary tract dysfunction must include a detailed history, emphasising voiding pattern, bowel habit, and neurological status. A diary (frequency volume chart), completed at home over a period of one week, recording the number of voids during the day and night and episodes of incontinence, is particularly useful. Examination of the abdomen, genitalia, lumbosacral spine, and lower limbs is essential. The child is observed voiding and a urine flow rate obtained (uroflometry). The value of this study is dependent on the child voiding an adequate volume, usually greater than $100 \mathrm{ml}$, into the flow meter. An ultrasound scan before and after micturition to measure bladder capacity (voided volume plus residual volume) and assess the presence of diverticula, bladder wall thickness, and upper tract dilatation provides further additional information. The urine is examined for organisms and protein. This simple protocol can exclude major lower tract dysfunction without recourse to more invasive procedures.

\section{Cystometry}

Cystometry refers to the measurement of the intravesical pressure/volume relationships and requires both bladder and rectal catheterisation. The main aim of cystometry must be to reproduce as accurately as possible the child's pattern of micturition when he or she is awake, nonsedated, and cooperative. ${ }^{2}$ In children the type of bladder access is of particular importance as the level of cooperation decreases in direct proportion to the discomfort of the study. For this reason the suprapubic route of bladder 